\title{
Evaluating firms' financial performance in textile industry of Romania
}

\author{
DOI: $10.35530 / I T .070 .03 .1398$
}

\section{Evaluarea performanței financiare a firmelor din industria textilă din România}

Evaluarea performanței financiare a unei firme sau a unui sector este o problemă importantă pentru managerii, investitorii și partenerii de afaceri. Informațiile de bază utilizate pentru evaluarea performanței financiare se găsesc în situațiile financiare. Precizia metodei utilizate pentru această evaluare depinde de exactitatea situațiilor financiare furnizate de firme care reflectă activitatea desfășurată. În această lucrare propunem un indice agregat pentru evaluarea performanței financiare, pe baza a 11 rate financiare selectate. Metoda a fost aplicată pe un eșantion de 82 de întreprinderi mijlocii care activează în sectorul textil din România. Industria textilă este o industrie cu tradiție și un sector important al economiei românești, atât în ceea ce privește contribuția la produsul intern brut, cât și creșterea exporturilor; a suferit în ultimii 20 de ani o perioadă dificilă de transformare și adaptare la o piață în schimbare, dar are un avantaj competitiv raportat la cel european, în principal datorită forței de muncă cu costuri reduse. Rezultatele cercetării arată ierarhia firmelor din sectorul textil în funcție de scorul performanței financiare, 42,68\% dintre firme având un scor mai mare decât media sectorului. Rezultatele sunt utile, în special pentru manageri, prin îmbunătățirea procesului de luare a deciziilor privind finanțarea și dezvoltarea afacerilor, prognozarea viitoarei performanțe financiare, selectarea partenerilor de afaceri, realizarea de investiții profitabile, dar și pentru analiștii financiari în îndeplinirea obiectivelor de afaceri.

Cuvinte-cheie: informații contabile, luarea deciziilor; indice agregat, scorul ferm, întreprinderi mijlocii

\section{Evaluating firms' financial performance in textile industry of Romania}

Assessing the financial performance of a firm or sector is an important issue for managers, investors and business partners. The basic information used for financial performance assessment is found in financial statements. The accuracy of the method used for this evaluation depends on the accuracy of financial statements provided by firms that reflect the activity developed. In this paper we propose an aggregated index for evaluation the financial performance, based on 11 selected financial rates. The method was applied on a sample of 82 medium-sized companies acting in the Romanian textile sector. Textile industry is an industry with tradition and an important sector of Romanian economy, both in terms of the contribution to gross domestic product and export growth; it has undergone in the last 20 years a difficult period of transformation and adaptation to a changing market, but has a competitive advantage reported to the European one, mainly due to low-cost labour force. The research results show the hierarchy of the textile firms after financial performance score, $42.68 \%$ of firms having a score above sector average. The results are useful, especially to managers, by improving decision making of business funding and development, forecasting the future financial performance, selecting business partners, making profitable investments, and to financial analysts in fulfilment of business objectives.

Keywords: accounting information, decision making, aggregated index, firm score, medium-sized firms

\section{INTRODUCTION}

Financial performance assessment is currently an important topic among managers, shareholders, investors, creditors, financial analysts and also researchers. Numerous theoretical and practical articles present different ways to measure the financial performance, for many and diverse sectors, for example: iron and steel industry [1], manufacturing [2], agriculture [3], retail [4], hotels industry [5], transportation [3, 6], financial investments, banks [7-8], insurance companies [9].The necessity for managers, investors, business partners and financial analysts is that these methods must be more efficiently, easy to apply, and show the real financial performance in order to make decisions for increase the performance, develop activity or avoid bankruptcy, to make good and profitable investments, to choose solvent business partners and realize a hierarchy and comparative analysis of the firms acting in a sector, and/or a certain period. The evaluation of financial performance depends on the accuracy of accounting information.

The quality of accounting information can reduce a firm's exposure to systematic liquidity risk and can affect firm valuation and cost-of-capital through their impact on different aspects of liquidity, especially when some events (e.g. financial crisis) may arise. Thus is confirmed the important role of accounting information during liquidity events [10]. The use of proper accounting information and analytic techniques can help a tolerated union of necessity between revenue management programs and firm strategy [11] that can increase financial performance of firms. After analysing various studies performed by theorists in the field [12-13] we concluded that the accounting information in an enterprise foresees the critical decisions that influence the decision to facilitate information for management control as well. We 
note that the accounting information has, as a starting point, two different and uneven sources in terms of quality, that information coming as a result of transactions carried out on various markets being seen during the financial year, having a rigorous and objective character, and that information known at the end of the year that is largely the result of estimates and reflects the accounting policies of the enterprise management.

The usefulness of accounting information increases if it is comparable, verifiable, readily available and understandable. Relevance and faithful representation of the accounting information are considered fundamental qualitative characteristics because it is used for calculation of a wide range of indicators in financial analysis and diagnosis. The main users of accounting information issued in a firm are: current and potential investors, the firm management, employees, financial and trade creditors, customers, financial analysts, the government and its institutions, and the general public, each of them having specific interests.

Hall considers that managers primarily use accounting information to develop knowledge of their work environment rather than as an input into specific decision-making scenarios [14]. In this role, accounting information can help managers to develop knowledge to prepare for unknown future decisions and activities. We know that accounting information is just one part of the wider information set that managers using to decision making and the quality of decisions depend on other sources of information at a manager's disposal. Also, managers interact with information and other managers utilising and verbal forms of communication that is not based on written reports. For investors, accounting information has a valuation role, providing investors with information for making informed investment decisions, especially in capital allocation. Private-equity firms require accounting information to control the conflicts of interest both within the private-equity firm (between the general and limited partners) and within their investors. Controlling these conflicts shifts the role of accounting back toward its original stewardship roots [15]. The role of accounting information's can be viewed in shaping user perceptions by providing new evidence that the descriptive valence of accounting constructs can impact consumer purchase decisions [16].

The aim of this paper is to propose an aggregated index for evaluation the financial performance, based on 11 selected financial rates. The paper also highlights the role that accounting information holds in a firm in financial decisions making of investors and managers, aimed at strengthening of the financial performance and value of firm. The aggregated index proposed for evaluation financial performance provides relevant information for stakeholders, investors, business partners, banks or other financial institutions, financial analysts, as well for researches that can use these indicators in financial analysis, research studies and forecasting activities. Also this aggregated index can establish a hierarchy of the companies acting in a certain sector. In this paper, for experimental part we have chosen the textile industry from Romania, which is not discussed in extensive studies in economics, thus making important contributions to the studied field.

\section{METHODOLOGY}

In order to make strategic decisions in firms, Mereuţă [17] proposed the CEMATT method that is a multi-criteria diagnostic tool for the condition of a firm, based on 6 components: financial, marketing, technology, quality, general management and human resources [18]. We consider that most of the strategic decisions in firms are based on accounting information that underlies the calculation of financial indicators used for assessing the financial performance of firms; this is key information for managers, investors and creditors. We know that financial position of a firm is highlighted by the relationship between assets, liabilities and equity that show a certain level of financial performance. Information about all these financial structures is provided by the Balance sheet and Profit and Loss account of firms. Thus, for our aggregated index we selected a number of 11 indicators, described in table 1.

These 11 indicators selected are usually used in financial diagnosis that is a tool oriented towards users aiming at measuring the return on capital and risk, the assessment of the conditions for achieving financial balance and the degree of autonomy, that are important in decision making in firms related to suspending activities, redefining the strategy or policy on long-term or short-term. The majority of the indicators included in the aggregated index are internationally recognized and used individually in financial performance analysis: profitability as return on assets and return on equity, financial autonomy [19], liquidity [19-20], ownership structure [21-22], capital structure and risk management [21]; debt [22], size [23], sales [24] etc.

The evaluation mechanism of the aggregated index goes on the principle that each criterion $i$ in the aggregated index sets a number of points (score) $S_{i}$, where $i=1 \div 11$ with the characteristic that $S_{i}$, belongs to the set $S_{j}=\{20,40,60,80,100\}$ specific for each criterion. The minimum element of the set, namely 20 , is the score given to a criterion which is a statement of total or nearly-total maladjustment to the requirements of a market economy; the maximum score $S_{i}$, set is 100 and represents a case of satisfying a requirement at high-international level. In order to grant these scores $S_{i}$, for each criterion $i$ were established intervals of performance (table 2), according to the limits and favourable values of each indicators known from the financial literature.

After awarding scores, it can be achieved the classification of companies after financial performance by determining the aggregate index for each firm. The aggregate index of each firm is a weighted average of the scores $S_{i}$ granted to each criterion $i$ of the aggregated index, having as weighting coefficients 


\section{INDICATORS INCLUDED IN THE AGGREGATED INDEX}

\begin{tabular}{|c|c|c|}
\hline No. & Indicators & Indicators description \\
\hline 1. & Return on assets (ROA) & Operating results $\times 100 /$ Total assets \\
\hline 2. & Return on equity (ROE) & Net results $\times 100 /$ Equity \\
\hline 3. & Invested capital productivity (ICP) & Net sales $\times 100 /$ Fixed assets \\
\hline 4. & Long-term debt ratio (LTDR) & Long-term debts $\times 100 /$ (Long-term debts + Equity) \\
\hline 5. & $\begin{array}{l}\text { Long-term debts scaled to self-financ- } \\
\text { ing capacity (LTDSFC) }\end{array}$ & Long-term debts $\times 100 /$ Self-financing capacity \\
\hline 6. & Patrimonial liquidity (PL) & $\begin{array}{l}\text { (Current assets + Prepaids) } \times 100 /(\text { Current liabilities }- \text { Revenues in } \\
\text { advance) }\end{array}$ \\
\hline 7. & Current assets turnover (CAT) & (Current assets + Prepaids) $\times 365 /$ Net sales \\
\hline 8. & Reduced liquidity $(\mathrm{RL})$ & (Current assets + Prepaids - Inventories) $\times 365$ / Current liabilities \\
\hline 9. & Patrimonial solvability (PS) & Equity $\times 100 /$ Total liabilities \\
\hline 10. & Quick ratio (QR) & Cash and cash equivalent $\times 100 /$ Current liabilities \\
\hline 11. & Financial leverage (FL) & Long-term debts $\times 100 /$ Equity \\
\hline
\end{tabular}

Note: Self-financing capacity is determined as Net income + Depreciation \& Amortization.

\begin{tabular}{|l|c|c|c|c|c|c|}
\hline \multicolumn{9}{|c|}{ SCORES FOR INDICATORS VALUE } \\
\hline \multirow{2}{*}{ No. } & \multicolumn{1}{|c|}{ Criterion designation } & \multicolumn{4}{c|}{ Indicators scores } \\
\cline { 3 - 7 } & \multicolumn{2}{|c|}{20} & 40 & 60 & 80 & 100 \\
\hline 1. & ROA (should not decrease below 10\%) & $<4$ & $(4-10]$ & $(10-15]$ & $(15-20]$ & $>20$ \\
\hline 2. & ROE (should not decrease below 5\%) & $<2$ & $(2-5]$ & $(5-10]$ & $(10-15]$ & $>15$ \\
\hline 3. & ICP (should not decrease below 2) & $<2$ & $(2-3]$ & $(3-4]$ & $(4-5]$ & $>5$ \\
\hline 4. & LTDR (should not increase over 80\%) & $>80$ & $(60-80]$ & $(40-60]$ & $(20-40]$ & $<20$ \\
\hline 5. & LTDSFC (should not increase over 4) & $>22$ & $(22-16]$ & $(16-10]$ & $(10-4]$ & $<4$ \\
\hline 6. & PL (should not decrease below 1,30) & $<1.30$ & $(1.30-1.80]$ & $(1.80-2.30]$ & $(2.30-2.80$ & $>2.80$ \\
\hline 7. & CAT & $>320$ & $(290-320]$ & $(160-290]$ & $(30-160]$ & $<30$ \\
\hline 8. & RL (should not be lower than 1) & $<1.00$ & $(1.00-1.20]$ & $(1.20-1.40]$ & $(1.40-1.60]$ & $>1.60$ \\
\hline 9. & PS & $<25$ & $(25-50]$ & $(50-75]$ & $(75-100]$ & $>100$ \\
\hline 10. & QR & $<0.25$ & $(0.25-0.50]$ & $(0.50-0.75]$ & $(0.75 \mathrm{v} 1.00]$ & $>1.00$ \\
\hline 11. & FL (should not increase above 1) & $>1.75$ & $(1.75-1.50]$ & $(1.50-1.25]$ & $(1.25-1.00]$ & $<1.00$ \\
\hline
\end{tabular}

the coefficients of importance $K_{i}$ of each criterion $i$, that are set according to the degree of importance:

$-K_{i}=5$ for a very important criterion, that means consequences of failure are extremely serious for the whole accomplishment. There were considered very important criteria: ROE, LTDR, LTDSFC, RL and QR; $-K_{i}=2$ for a major criterion, that means consequences of failure are severe but only at the level of sections or departments. There were considered major criteria: ROA and $\mathrm{FL}$;

- $K_{i}=1$ for a secondary criterion, that means consequences of failure have isolated effects. There were considered secondary criteria: ICP, PL, CAT and PS. The degree of importance in establishing the coefficients was determined in accordance with the aim of the paper, that is the assessment of the level of financial performance of firms and the sector using the proposed aggregated index, and also establishing a hierarchy between companies acting in the sector, that can be used for decision making of managers, investors and creditors. The scale 5, 2 and 1 chosen for the degree of importance was maintained similar with the specifications from CEMATT model. The aggregated index of financial performance $\left(S_{F P}\right)$ is calculated by the relation:

$$
S_{F P}=\sum_{i=1}^{n} K_{i} \times S_{i} / \sum_{i=1}^{n} K_{i}
$$

After this aggregate score of financial performance, firms can be included in the following categories: (i) [0-20] - masked bankruptcy - detection of profit centres and triggering procedures for firm cession; (ii) (20-40] - critical situation - radical restructuring, taking measures for overcoming the "alarm thresholds", significant restrictions of activity, important changes of profile/markets, capital inflows; (iii) (40-60] - difficult balance - major restructuring, new targets in the short/medium term, commercial marketing activities, improving management and drastic 
savings regime, capital inflows; (iv) (60-80] - satisfactory adaptation - selection of strategic objectives, "freezing" unprofitable businesses, capital inflows; (v) (80-100] - validity in competitive environments adopting a firm offensive strategy in this case major restructuring is not necessary.

\section{EXPERIMENTAL WORK}

The methodology presented for evaluation financial performance is applied on firms acting in textile industry. The apparel and textile industry is one of the longest and most complicated industrial chains in manufacturing industry. It is fragmented and dominated by SME's, with a demand driven mainly by three end-uses: clothing, home and technical textiles. This industry is composed of a wide number of subsectors, covering the entire production cycle from the production of raw material to semi processed and final products [25].

Textile industry an important sector of national economy, both in terms of the contribution to gross domestic product and export growth, and in Romania has undergone in the last 20 years a difficult period of transformation and adaptation to a changing market. Romania is endowed with the necessary resources for the production of fibers and fiber silk and wool, flax and hemp bastfibers, but it still needs huge investments. Therefore, the industry is dependent on imports of raw materials [26].

We have chosen for case study the textile and clothing industry because, in Romania, is an industry with tradition and companies operating for over 100 years. Romania's competitive advantage in textile industry reported to the European one, is mainly due to lowcost labor force [26], creation of a great number of jobs, especially female, contribution to social stability being represented in all counties, skilled and experienced staff, proximity to Western countries, no taxes in EU membership and compliance with EU standards and regulations [27]. It is a sector that uses intensive labour force and has a significant share in the export economy and contributes with profit to the foreign trade balance of the country. According to the classification of value added per employee, Romania occupies the last place ahead of Bulgaria and the value added to total labor costs in industry exceeds the EU average for textile and clothing [28]. The production of textile clothing in Romania has recorded approximately 2.5 billion EUR in 2013 , up by almost $4 \%$ compared to 2012. Although during the first 8 months of 2014 , the turnover value index in textile manufacturing sector has increases by $16.4 \%$ compared to the same period of 2013 [27]. Romania has a very small share in the turnover of the EU, compared to the large number of employees in this industry. Romania has the largest undeveloped export potential in the textile industry of the EU countries, about $15 \%$ of the entire EU unexploited potential [28]. Study data were selected from Amadeus database, provided by Bureau van Dijk Electronics, from among medium-sized enterprises, active in 2014 in the clothing industry in Romania (with a number of employees between 50 and 249), with activity conducted within the NACE code 14 - Manufacture of wearing apparel (14.13). Thus, 366 active companies were identified in the database, 20 of which have been removed, for which the database does not provide comprehensive data. Of the 346 valid businesses, further on in the study, we will focus only on the first 82 mediumsized companies with total assets greater than 1 million Euro, that represents $23.70 \%$ of the active medium-sized firms in textile industry in Romania. For the sample of 82 companies were calculated indicators defined in table 1 using data from the database built for this study. The results are presented in Appendix (table 4). It was found that, in most cases, the analysed indicators are not within the normal ranges found in industry. For example, in the case of many firms, we have indicators greater than $5 \%$, when return on equity was determined, or greater than the maximum allowed recorded by the leverage ratio, which is $80 \%$. The examples that do not fit may continue in the case of patrimonial liquidity as well, where a normal value should not fall below 1.30. Misfit occurs in the case of patrimonial liquidity, where a normal value should be between 1.5 and 2, and in the case of solvency values, greater values than 1 must exist. But nevertheless, there are only 4 companies from 82 that fall within the normal range to all criteria.

In relation to the analysed companies, the scores awarded can be viewed in the Appendix (table 5) for the sector and for each firm. For the sector, basic indicators were determined adding the value registered by all firms included in the sample, the average score of the sector being 73.33. Please note that the range of variation was determined by the authors to frame the companies within the analysed indicators and equally depending on the specific of textile industry. Thus, for each firm, the scores for each indicator were granted, depending on the scale described on methodology. In Appendix (table 5), companies were ranked by the aggregate score obtained, in descending order, for a better observation of the position each firm. We found that the companies' situation is a good one seen in terms of the aggregate scores, although many of the 11 financial indicators fell outside the normal values in the industry.

\section{RESULTS AND DISCUSSION}

In table 3, we show the framing of companies after the level financial performance in a category of performance. Although the sector score determined as we presented above is framed on the interval (70-80] where we find the most companies; statistically, the average score of performance is 66.32 and standard deviation is 19.284. We can conclude that most medium-sized companies in the textile industry in Romania fall into the category 60-80, which means that companies operate under optimal conditions, and that could give them a very good rating. Also note that in the analysis there have not been registered companies classified in the lowest category, 
INTERVALS OF PERFORMANCE AFTER FIRMS' SCORES

\begin{tabular}{|c|c|}
\hline Firms score interval & No. of companies \\
\hline $\mathbf{( 9 0 - 1 0 0 ]}$ & 9 \\
\hline $\mathbf{( 8 0 - 9 0 ]}$ & 11 \\
\hline $\mathbf{( 7 0 - 8 0 ]}$ & 18 \\
\hline $\mathbf{( 6 0 - 7 0 ]}$ & 14 \\
\hline $\mathbf{( 5 0 - 6 0}]$ & 14 \\
\hline $\mathbf{( 4 0 - 5 0 ]}$ & 7 \\
\hline $\mathbf{( 3 0 - 4 0 ]}$ & 6 \\
\hline $\mathbf{( 2 0 - 3 0 ]}$ & 3 \\
\hline No. of companies & $\mathbf{8 2}$ \\
\hline
\end{tabular}

and so they may not be considered bankrupt. However, we believe that most companies are found to be working in normal operating parameters. Thus, over the sector score were found $42.68 \%$ of firms studied.

The results of the aggregated index are relevant for managers and owners that can find the position of their firm in the sector according to financial performance, can assess the evolution of financial performance in a certain period, can know the main competitors or the companies with similar financial performance, and also can forecast the financial performance for future years. Also, this information allows managers and owners to lead in decision making for improvement of financial performance. Financial analysts can realise comparative studies of financial performance between activity sectors and firms, for the same period (comparing different sectors and/or firms) and different periods of time (comparing the evolution of financial performance in the same sector and/or firm).

\section{CONCLUSIONS}

As a result, we conclude that the accounting information is really an important source for determining the financial position and performance of companies. In financial decision making at firm level, financial statements must be consulted, primarily the balance sheet and profit and loss account, which show the position, respectively the financial performance. It was found that the accounting information can be the key in decision making in the management of a firm. It also represents an important junction between the management, where decisions are made, and the finance, where financial situations are prepared. Thus, in conclusion, we say that the accounting information helps in making financial decisions within a firm.

This study was conducted on a database of middlesized companies in the Romanian textile industry after a selected criterion in order to determine the financial position and their relevance for theoreticians that can design on it financial models, and stakeholders that substantiate their decisions according to the firm performance. We proposed this aggregated index, based on financial indicators, in order to assess the financial performance of firms. We found that there was an almost equal ratio of firms in the first three categories, and no firm has been found bankrupt. We conclude on this case study indicating that the average firm score of the 82 companies is a good one, equal to 66.32 , so we can say that overall, medium-sized companies in the textile industry are in financial balance.

The idea of this research brings great benefits to theoreticians, researchers in economics and not only, but also to practitioners, to firms in order to achieve financial diagnosis, to identify financial problems and financial position within its field. Thus, managers can evaluate the financial performance of the firm in a certain period and can improve decision making when the financial performance of the firm decrease. The study offers relevant information for other stakeholders: for creditors, the firm score being a tool in granting funding process; for employees that search high labour productivity; for owners in order to make decision of investments or to take decisions for improving the firm performance; for suppliers, the high score of a firm indicating a good management and the desire to be business partner for such a firm; for government, this score being important in providing grants or subsidies for firm investments.

\section{BIBLIOGRAPHY}

[1] Ma, J., Evans, D., Fuller, R., Stewart, D. Technical efficiency and productivity change of China's iron and steel industry, In: International Journal of Production Economics, 2002, vol. 76, no. 3, pp. 293-312.

[2] Zhang, H., Li, L., Zhou, D., Zhou, P. Political connections, government subsidies and company financial performance: Evidence from renewable energy manufacturing in China, In: Renewable Energy, 2014, vol. 63, pp. 330-336.

[3] Chen, P., Yu, M., Chang, C., Hsu, S. Total factor productivity growth in China's agricultural sector, In: China Economic Review, 2008, vol. 19, no. 4, pp. 580-593.

[4] Yua, W., Ramanathan, R., Nath, P. The impacts of marketing and operations capabilities on financial performance in the UK retail sector: A resource-based perspective, In: Industrial Marketing Management, 2014, vol. 43, pp. 25-31.

[5] Chen, C.-M., Chang, C.-L. Diversification strategy and financial performance in the Taiwanese hotel industry, In: International Journal of Hospitality Management, 2012, vol. 31, pp. 1030-1032.

[6] Barros, C.P., and Peypoch, N. An evaluation of European airlines'operational performance, In: International Journal of Production Economics, 2009, vol. 122, no. 2, pp. 525-533. 
[7] Ongore, V.O., Kusa, G.B. Determinants of financial performance of commercial banks in Kenya, In: International Journal of Economics and Financial Issues, 2013, vol. 3, no. 1, pp. 237-252.

[8] Mukherjee, K., Ray, S., Miller, S. Productivity growth in large US commercial banks: the initial post-deregulation experience, Journal of Banking and Finance, 2001, vol. 25, pp. 913-939.

[9] Adams, M., Buckle, M. The determinants of corporate financial performance in the Bermuda insurance market, In: Applied Financial Economics, 2003, vol. 13, pp. 133-143.

[10] Sadka, R. Liquidity risk and accounting information, In: Journal of Accounting and Economics, 2011, vol. 52, no. 2-3, pp. 144-152.

[11] Huefner, R.J., Largay, J.A. The role of accounting information in revenue management, In: Business Horizons, 2008, vol. 51, no. 3, pp. 245-255.

[12] Bushman, R., Chen, Q., Engel, E., Smith, A. Financial accounting information, organizational complexity and corporate governance systems, In: Journal of Accounting and Economics, 2004, vol. 37, pp. 167-201.

[13] Danos, P., Holt, D.L., Imhoff, E. Jr. The use of accounting information in bank lending decisions, In: Accounting Organizations and Society, 1989, vol. 14, no. 3, pp. 235-246.

[14] Hall, M. Accounting information and managerial work, In: Accounting, Organizations and Society, 2010, vol. 35, no. 3, pp. 301-315.

[15] Zimmerman, J.L. The role of accounting in the twenty-first century firm, In: Accounting and Business Research, 2015, vol. 45, no. 4, pp. 485-509.

[16] Tian, Y., Zhou, H. From bottom line to consumers' mind: The framing effects of accounting information, In: Accounting, Organizations and Society, 2015, vol. 43, pp. 56-66.

[17] Mereuţă, C. Analiza diagnostic a societăţilor comerciale în tranziţie: Metoda CEMATT, 1994, Bucharest: Tehnica.

[18] Alexa, V., Kiss, I., Ratiu, S. Diagnostic analysis - tool in research and innovation, In: Annals of Faculty Engineering Hunedoara, 2013, vol. 11, pp. 321-324.

[19] Horta, I.M., Camanho, A.S., Moreira da Costa, J. Performance assessment of construction companies: A study of factors promoting financial soundness and innovation in the industry, In: International Journal of Production Economics, 2012, vol. 137, no. 1, pp. 84-93.

[20] Gurbuz, A.O., Aybars, A., Kutlu, O. Corporate governance and financial performance with a perspective on institutional ownership: empirical evidence from Turkey, In: Journal of Applied Management Accounting Research, 2010, vol. 8, pp. 21-38.

[21] Mirza, S.A., Javed, A. Determinants of financial performance of a company: Case of Pakistani stock market, In: Journal of Economics and International Finance, 2013, vol. 5, no. 2, pp. 43-52.

[22] Saliha, T., Abdessatar, A. The determinants of financial performance: an empirical test using the simultaneous equations method, In: Economics and Finance Review, 2011, vol. 1, no. 10, pp. 01-19.

[23] Love, I., Rachinsky, A. Corporate governance, ownership and bank performance in emerging markets: evidence from Russia and Ukraine, Siteresources-worldbank. 2007, Working Paper.

[24] Forbes, K.J. How do large depreciations affect company performance?, In: IMF Staff papers, Palgrave Macmillan, 2002, vol. 49, no. 1, pp. 214-238.

[25] Adinolfi, R., Andersen, T. In-depth assessment of the situation of the T\&C sector in the EU and prospects, In: Final Report ENTR/2010/16 Prepared for European Commission Enterprise and Industry DG, October 2011.

[26] Şerbănel, C.I. Romanian textile industry and its competitive advantage, In: SEA - Practical Application of Science, 2014, vol. 2, no. 2 (4), pp. 395-404.

[27] FRD Centre Market Entry Services, Garments Market in Romania, 2015, available at http://www.frdcenter.ro/assets/ Garments-Market-Romania-2015-DEMO-Sector-Brief.pdf

[28] Gîrneaţă, A. Increasing managerial capability in Romanian textile companies, In: Proceedings of the $7^{\text {th }}$ International Management Conference "New Management for the New Economy", November 7th-8th, 2013, Bucharest, Romania.

\section{Authors:}

\section{TEODOR HADA ${ }^{1}$, NICOLETA BĂRBUŢ̆-MIŞU², TEODORA MARIA AVRAM}

1"Bogdan Vodă" University, Faculty of Economic Sciences, Department of Management-Finance-Accounting, 26A Grigore Alexandrescu, 400560, Cluj-Napoca, Romania

2“Dunarea de Jos” University of Galati, Faculty of Economics and Business Administration, Department of Business Administration, 800008, Galati, Romania

3“1 Decembrie 1918" University, Faculty of Economic Sciences, PhD Student, 5 Gabriel Bethlen, 510009, Alba Iulia, Romania

e-mail: teohada@yahoo.com; Nicoleta.Barbuta@ugal.ro; avram_teodora@ymail.com

Corresponding author:

NICOLETA BĂRBUŢ̆-MIŞU

e-mail: Nicoleta.Barbuta@ugal.ro 